\title{
Corrupt and Rapacious: Colonial Spanish-American Past Through the Eyes of Early Nineteenth-Century Contemporaries. A Contribution from the History of Emotions
}

\section{Moisés Prieto}

\section{INTRODUCTION}

A spirit of corruption has infected all the colonies of Spain in America. Men far removed from the seat of government; impatient to acquire wealth, that they may return speedily from what they are apt to consider as a state of exile in a remote unhealthful country; allured by opportunities too tempting to be resisted, and seduced by the example of those around them; find their sentiments of honour and of duty gradually relax. In private life they give themselves up to a dissolute luxury, while in their public conduct they become unmindful of what they owe to their sovereign [King Philip II of Spain] and to their country. ${ }^{1}$

\footnotetext{
M. Prieto $(\bowtie)$

University of Bern, Bern, Switzerland e-mail: moises.prieto@hist.unibe.ch
}

(C) The Author(s) 2021

R. Kroeze et al. (eds.), Corruption, Empire and Colonialism in the Modern Era, Palgrave Studies in Comparative Global History, https://doi.org/10.1007/978-981-16-0255-9_5 
This quote from the opus by Reverend William Robertson (17211793) on the history of Spanish America, first published in 1777, shows how corruption is considered to be a consequence-or at least a favourable circumstance-of the distance between the colonies and metropolitan Spain. It also points to the general challenges of colonial administration combined with the very own passions of men in power. ${ }^{2}$ Moreover, the above quote reflects two important aspects: a transatlantic if not even global focus conditioned by a political and historical awareness, very much in line with Edward Gibbon's The History of the Decline and Fall of the Roman Empire (1776-1789); and a consciousness of sentiments by means of references to "honour" and "duty", ${ }^{3}$ thus appealing the reader to a repertoire of sentiments he or she might be able to decode and understand. The awakening of emotions and their reflection in texts, mainly in Enlightenment France, was the starting point for a radical and inexorable development chiefly inspired by the writings of Genevan philosopher Jean-Jacques Rousseau (1712-1778). ${ }^{4}$ The same author and his writings have to be considered also a cardinal point for the awakening of corruption critique in the second half of the eighteenth century. ${ }^{5}$ This raises the question about the possibility of deconstructing corruption and anti-corruption discourses in their emotional components.

The semantic extension of "corruption" was based on the development of a new ethos under the auspices of the Enlightenment. ${ }^{6}$ Also, the writings of Charles-Louis de Secondat de Montesquieu (1689-1755) L'Esprit des lois-show the importance of virtue, honour and fear in the building of a society freed from corruption. Montesquieu rescued the ancient Roman ethos in the sense of a political virtue; that is, the placing of all energies in the service of their city, to renounce to one self's expectation and for the sake of higher purposes. ${ }^{7}$

German historian Jens Ivo Engels distinguishes three meanings of "corruption": physical, moral and political corruption. ${ }^{8}$ In fact, most of the sources used for this article contain references to the latter form, although "moral decay" (in French corruption des mours) appears as another common meaning, actually paving the way to "the misuse of public office for private advantage or profit". 9 Without specifying the meaning of "corruption" for this particular case-which may include nepotism, clientelism, fraud, malversation, bribery and different forms of extortion-there is nowadays a general consensus on the pervasiveness of this phenomenon in colonial Spanish America, until the very 
end of colonial rule and beyond. ${ }^{10}$ The metaphor of congregated officeholders drinking chocolate, as mentioned in Pol Dalmau's contribution for the case of late nineteenth-century colonial Cuba, perfectly synthesises this idea. Moreover, the consensus on the ubiquity of corruption in the Spanish colonial empire already started among late eighteenth and early nineteenth-century historians. ${ }^{11}$ However, different sources report a mitigation of this evil by means of reforms inspired by the ideas of the Age of Reason. For instance, both the above-mentioned Reverend Robertson and Prussian polymath and explorer Alexander von Humboldt (1769-1859) appreciated the improvements brought by José de Gálvez (1720-1787), first royal Visitor-General in charge of studying the colonial administrative structures in America, and then Minister of the Indies under King Charles III of Spain. ${ }^{12}$

The early nineteenth century is generally considered the epoch of America's "second discovery". ${ }^{13}$ Mainly inspired by Alexander von Humboldt, merchants, travellers, scientists like Charles Darwin (18091882) or Alcide d'Orbigny (1802-1857) and adventurers like Louis Henri Ducoudray Holstein (1772-1839) travelled through Latin America with different purposes. They wrote down their experiences as travel reports which were avidly read in Europe. These documents were not only supposed to provide mere entertainment or knowledge about local customs, flora and fauna, but sometimes contained historical essays on the recent past of those former colonies. In fact, those young republics were now ruled by strongmen who, in some cases, were deeply inspired by the ideas of the European Enlightenment and consequently by an ethos of rectitude, which reached enlightened absolutism too in the shape of the dictum "the prince is the first state servant". ${ }^{14}$ Nevertheless, nepotism, favouritism, misappropriation, bribery or arbitrariness were still present in those accounts which tried to explain these phenomena in different ways. This raises the questions on the narratives of corruption, how they were built, what moral lens and what patterns of explanation were used. What historical models were used as a comparison and what emotions are involved within the narrative on corruption?

This chapter endeavours to discuss different views from travellers, historians and dissidents upon colonial Spanish America. The geographical focus will be on three regions: New Spain (now Mexico), Paraguay and Buenos Aires. The rising importance of the history of emotions, of which the history of corruption has paid little attention, is justified for providing an additional layer of plausibility, but also for being an 
increasing phenomenon in political discourses-as I already stated above. In doing so, new insights may be gained about those narratives which were often controversial and not always consistently resorted to. While the history of corruption has been a subject attended to by historians of economy and law, it seems that those untamed passions at the very origin of corruption should now probably be unveiled under the auspices of the history of emotions. Nevertheless, it is important to point out that the historical treatment of sentiments bears some perils too, since the interpretation of feelings can vary depending on the epoch, the social stratum and the cultural space. ${ }^{15}$ For the above purpose, the set of sources used will be composed of historical essays, treaties, reports and political pamphlets-all of them containing comments on corruption.

If we believe that the Enlightenment provided the "healing powers" for the palliation of corruption, it is necessary to point out the frame of such an intellectual spread within the Atlantic space. Already in 1978, Italian law historian Pierangelo Catalano remarked on the case of the dictator of Paraguay, Dr. José Gaspar Rodríguez de Francia-who held in his library authors such as Voltaire, Charles Rollin (Histoire romaine), Juan de Haller (Historia romana) and Jean-Jacques Rousseau (Contrat social) - that the dissemination of the ideas of Roman constitutional history was still an understudied topic. ${ }^{16}$ Back in 1999, John Lynch argued that "we still need a comprehensive study of Enlightenment ideas in Spanish America". ${ }^{17}$ The works of historians José Carlos Chiaramonte and Carlos Stoetzer, as well as those by Noemí Goldman and Gabriel Entin, have contributed to address the question on the transfer of knowledge in Spanish America, and particularly in the River Plate region, paving the way for further research. ${ }^{18}$

\section{Novohispanic Doléances}

An example for the perception of corruption might be provided by the great explorer with a global dimension and polymath himself. Alexander von Humboldt stated in his Essai politique sur le Royaume de la NouvelleEspagne, devoted to the description of the mining resources and the statistics of a region that would become today's Mexico ${ }^{19}$ : "The first choice of the persons to whom the count [sic] confided the important places of intendant or governor of a province was extremely fortunate. Among the twelve who shared the administration of the country in 1804, there was not one whom the public accused of corruption or want of 
integrity". ${ }^{20}$ While this argument stays in line with the fortunate policies of Gálvez, the Prussian savant had expressed his contempt for slavery and the discriminatory condition of the indigenous population. ${ }^{21}$ However, one could raise the question on Humboldt's honesty in praising the purported lack of corruption. After all, he was sponsored by the Spanish monarch, which would suggest disregarding some grievances in favour of punctual panegyrics. ${ }^{22}$ In doing so, Humboldt defends the colonial administration and the Crown's honour. This statement may be read twofold, since it can be a way to pay respect to King Charles IV and to his wise appointments, but also as an interlined statement. In other words, a claim on the general reputation of Spanish colonial administration; incorrupt officeholders appear here to be an exception and not as the rule. Considering Humboldt's condemnation of slavery, we probably should presume that the praise of the lack of corruption is sarcasm. Thus, Humboldt's thoughts show affinities with those from a contemporary Mexican patriot and priest; i.e. Fray Servando Teresa de Mier (1765-1827), who addressed the corrupt colonial administration in his writings. $^{23}$

Also, German-speaking historiography was aware of corruption in the Spanish-American colonies, as the work by historian and translator Franz Kottenkamp (1806-1858) attests. The following quote by Kottenkamp, which might very much be an analogous transliteration of the above by Reverend Robertson, explains corruption as a consequence of a caste of awkward, ignorant and greedy bureaucrats, as he writes:

The government itself suffered significant damage to its revenues as a result of this administration's composition. In a pure bureaucracy, where strict control is impossible because of the distance from the centre, bribery is a necessary consequence. Moreover, all Spaniards had quick enrichment and return to the motherland in mind, motives to use the means all the more eagerly, which could carry them quickly. ${ }^{24}$

Such an unjust system could no longer be tolerable, especially in a region exposed to the dissemination of enlightened thinkers despite the vigilant eye of the Spanish Inquisition. ${ }^{25}$ Thus critique gained public space. The essay edited by Carlos María de Bustamante (1774-1848) entitled Mexico por dentro y fuera, bajo el gobierno de los Vireyes (Mexico from inside and outside under the viceroys), written in 1787 by Hipólito Villarroel, but not published until $1831,{ }^{26}$ provides a deep insight into the elites and the 
civil and ecclesiastical authorities of New Spain. Villarroel was a Spanishborn social reformer and mayor of Tlapa. ${ }^{27}$ In his 190-page text the Mexican patriot resorts to the metaphor of pathology, considering corruption-among other evils-a disease manifested by means of determined "symptoms", for which particular remedies should be applied. Particularly harsh words are used to denote the judicial administration, starting from the judges themselves and extending throughout the hierarchy of judicial officers, advisors, scribes, etc. ${ }^{28}$ In such a system, the innocent is condemned while the criminal is set free; the perversion of justice to pursue private interests prevails. The salary increase for the members of the judicial caste, aimed at preventing bribery, did not fulfil their expectations. As a "therapy" against this evil, Villarroel suggested the suspension of the corrupt officers, which is considered a hard but necessary measure by the author: "Quod non sanat medicamentum, sanat ferrum: quod non sanat ignis, est insanabile". However, Villarroel still expressed some hope regarding the correction of those evils if a visitor-general dissolves the chaos. In writhing this, he stated his loyalty and confidence in the authority of the Spanish crown, thus underlining the need for reforms rather than an irreversible revolution.

Villarroel's repertoire of grievances has to be located in a global perspective within the practice of the so-called cabiers de doléances, which were at the origin of the French Revolution's emotional foundation. Although a format belonging to the ancien régime with its language of loyalty, ${ }^{29}$ the cabiers transported the claims for radical changes through the mobilisation of determined sentiments. These sentiments were the public wrath and indignation, amplified within the public space, no longer seen as an act of allegiance or a humble petition to the sovereign, but as a claim made on the basis of natural rights. ${ }^{30}$ Thus, "anger against tyranny and injustice" 31 became the motors of an irreversible and unstoppable change. This does not mean that Spanish Americans were simply "influenced" by the events in France or the American Revolution, ${ }^{32}$ but rather that they drew on the same "enlightened" sources and narratives. ${ }^{33}$ Nevertheless, according to Jeremy Adelman, Enlightenment-inspired corruption rhetoric did not aim at revolution per se. ${ }^{34}$

It is, however, important to point out that unlike the French, the subjects of the Spanish king in Latin America were far away from their sovereign. The celebrations with the occasion of Charles III's funeral, and the coronation of his son Charles IV in 1789, show the efforts 
to ingrain the love for the sovereign. ${ }^{35}$ Additionally, this illustrated the choreography of the feasts where the Spanish colonial elite and aristocracy's ostentation, in the face of the Creoles, created a clear distinction between the powerful and the powerless. ${ }^{36}$ Also, Kottenkamp mentioned in his compendium on the history of Spanish America the iniquities of the judicial system, with a particular emphasis on the discrimination of Creoles by the Spanish elite officeholders and bureaucrats. ${ }^{37}$

\begin{abstract}
A judge from Aragon made a different sentence than the one from Castile, who again deviated from the decision of another from Granada etc. Thus, the uncertainty of the law and of their own existence was added to the remaining inconvenience that the Creoles had to suffer from the motherland. The only antidote was the power of the Viceroy, who was able to nullify the verdict of the courts in the highest instance, thus adding the last unrestricted interpretation and application of the laws to his remaining power. The consequence of this may be easily imagined. Among the Creoles there was a general opinion that no trial against native Spaniards could be won by them without greater bribery. ${ }^{38}$
\end{abstract}

Thus, a sentiment of uncertainty and hopelessness becomes patent which, according to Kottenkamp, could only be palliated through the practice of bribery. In other words, within this narrative bribery would neutralise systemic corruption and iniquity of the colonial courts of justice. Royal authority exercised by the viceroys was, however, fading in those revolutionary years around 1810, which were characterised by the transition and transformation of public administration and meant, therefore, a challenge for foreign witnesses. A particularly peculiar transition was occurring in Paraguay, which belonged under Spanish colonial rule to the Viceroyalty of the Río de la Plata. There-unlike most other parts of Hispanic America where generally military leaders seized power-a theologian was about to climb the ladder of supreme authority.

\title{
The Incorruptible Dictator?
}

José Gaspar Rodríguez de Francia was born in 1766 in Yaguarón. ${ }^{39}$ His father was a Brazilian officer and tobacco trader, his mother the niece of a former governor and captain-general. Francia attended primary school and undergraduate studies in philosophy and theology in Asunción. Between 1778 and 1788, he studied at the Universidad Real de Córdoba del Tucumán, where he eventually was granted the title of 
Doctor en Sagrada Teología. He then returned to Asunción, where he practised law and taught theology. The Congress of Paraguay approved a new constitution with two consuls as chiefs of state, bound by the principle of collegiality, for the duration of one year. Dr. Francia and Colonel Fulgencio Yegros were elected to this new office in 1813. One year later, when the Congress had to renew the Consulate, Francia proposed another reform: a sole dictator should lead the country in order to save it from the influence of Europeans and secure national independence. Hence, Francia was elected dictator for a five-year term (dictador temporal). ${ }^{40}$ Notwithstanding the expiration of this term, in 1816 the Congress had already convened and voted to confer a lifetime dictatorship, and the right to convoke the Congress to Francia. ${ }^{41}$ During his entire dictatorship he did not convoke the Congress, which finally convened in 1840 - the year of his death.

The European public gained a stronger awareness of Francia through an essay written by Johann Rudolf Rengger (1795-1832), a Swiss doctor who travelled to Paraguay with his colleague Marcelin Longchamp (1794-1861) for research purposes. Their stay lasted from 1819 until 1825. Rengger and Longchamp wrote the Essai historique sur la révolution du Paraguay, et le gouvernement dictatorial du docteur Francia, along with German and English versions in 1827. In their essay, the two Swiss physicians sketched the history of the Paraguayan revolution with a strong focus on Francia's struggle for power as well as his personality traits. ${ }^{42}$ Leila Gómez describes the Essai historique as a meticulous attempt to scrutinise not only the Paraguayan prisons, but also the Paraguayan culture. ${ }^{43}$ The arbitrariness and ruthlessness reported in the text betray a clear contempt for Francia's policies, on the part of the authors. However, they also praised his virtues, such as incorruptibility and austerity, done by means of particular accounts within the essay. The first one deals with the origins of Francia's reputation as a lawyer, with particular noble principles opposed to the colonial system.

After returning to his own country from the university, Doctor Francia distinguished himself by a degree of courage and integrity which nothing could surmount. Never did he sully his function by undertaking an unjust cause: he readily defended the weak against the strong - the poor against the rich. He exacted large fees from those who could pay, and especially from those who were disposed to litigation; but he was extremely disinterested in dealing with those clients who were either in humble 
circumstances, or were reluctantly forced into the courts by the unjust conduct of others. ${ }^{4}$

This rough description was resumed in an account by the Robertson brothers. John Parish Robertson (1792-1843) and William Parish Robertson were two Scottish merchants who in 1812 and 1814, respectively, travelled to Paraguay with the purpose of establishing commercial relations. ${ }^{45}$ Francia expelled them in 1815, though they waited until the late 1830 s to take their "revenge". The authors chose an epistolary structure, where anecdotes and single reminiscences offered quite the opposite of a benevolent portrayal. The Robertsons' letters contained many references to the previously cited essay of Rengger and Longchamp. Nevertheless, as historian Günter Kahle points out, the polemical portions in the Robertsons' account are limited to those anecdotes and reports provided by third parties, while their personal experiences generally attested to the dictator's kind manners and gentle behaviour. ${ }^{46}$

Despite their contempt for the ruler of Paraguay, they still paid tribute to his rectitude through the following anecdote, which was narrated on the basis of the biblical story of Naboth's vineyard. Dr. Francia's advocacy was requested by a friend who wanted to possess a vineyard which belonged to a certain Estanislao Machain, ${ }^{47}$ who was a known enemy of Francia. The dictator declined to help his friend in a trial he considered an "unrighteous cause". Since his friend insisted, Francia decided to offer his legal services to Machain instead.

"The first 'escrito', or writing, sent in by Francia to the Juez de Alzada, or Judge of the Court of Appeal, confounded the adverse advocates, and staggered the judge, who was in their interest. 'My friend,' said the judge to the leading counsel, 'I cannot go forward in this matter, unless you bribe Dr. Francia to be silent.' 'I will try,' replied the advocate, and he went to Naboth's counsel with a hundred doubloons (about three hundred and fifty guineas,) which he offered him as a bribe to let the cause take its iniquitous course. Considering, too, that his best introduction would be a hint that this douceur was offered with the judge's concurrence, the knavish lawyer hinted to the upright one that such was the fact." However, Francia replied vigorously: "Out with your vile insinuations, and dross of gold from my house". Then, Francia went to the residence of the judge. "'Sir' continued Francia, 'you are a disgrace to law, and a blot upon justice. You are, moreover, completely in my power; and unless to-morrow I have a decision in favour of my client, I will make your seat upon the bench 
too hot for you, and the insignia of your judicial office shall become the emblems of your shame"”.

The judge pronounced himself in favour of Francia's client, who kept his vineyard. The judge's reputation vanished, while the courageous advocate's fame was consolidated. There are no indications about the sources of this account in the Robertsons' text. Since this episode was set before the emancipation from Spanish colonial rule, the authors could not have witnessed it. However, the anecdote became popular. Even Thomas Carlyle (1795-1881) reported it in his essay from 1843 entitled $D r$ Francia, where the Scottish author praised the virtues of the dictator. ${ }^{48}$ In the anecdote, corruption within the Spanish colonial judiciary system is shown in two ways. Firstly, it suggests the partiality of the judge who is in favour to support the unjust interests of the plaintiff. Secondly, the judge himself recommends the plaintiff to bribe the defendant's advocate, so that he shall betray his client and lose the cause. The account as such takes us back to the primordial meaning of corruption as a crime mainly perpetrated by a judge. ${ }^{49}$ Finally, the use of Naboth's biblical account as a narrative device might reveal a particular pattern of interpretation for corruption, too.

This use of justice, called empapelamiento, was a common practice to pursue material interests or to attack an enemy by means of judicial acts. ${ }^{50}$ This was also a typically gender-related practice, frequently resorted to by women in despair in order to obtain a fair extrajudicial agreement, or in order to repair offences of honour and reputation. ${ }^{51}$ In fact, towards the end of the eighteenth century, Spanish America witnessed an increased use of legal practices; a phenomenon Bianca Premo summarises as it follows:

Thus, beyond the legal arguments they marshaled to their cases, litigants practiced the Enlightenment in the very act of going to civil court. By repeatedly hauling 'tyrannical' domestic and community authority figures before royal judges, litigants made space for law as a system of rights and rules that transcended the hierarchical order of colonial society. ${ }^{52}$

Honour was a paramount aspect in this development. ${ }^{53}$ It mattered not if honour was not considered a proper emotion in the strict sense; early modern societies saw different conceptions of honour depending on social class, estate, gender and profession. ${ }^{54}$ The conceptual change of honour distinguishes the ancien régime notion of honour, based on blood nobility 
as opposed to the newer nobility of virtue. ${ }^{55}$ France witnessed a comeback of honour from the beginning of Napoleonic rule, but that was no longer attached to or exclusive of aristocracy. ${ }^{56}$

Sometimes the dictator's eulogy may be seen as implicitly opposed to the former situation during the ancien régime. The Robertsons sketch a situation of utmost colonial exploitation in spite of a legal frame disposed for its prevention.

The laws of the Indies, though framed in many respects with a humane tendency, and liberal policy, were seldom carried into effect, and almost never for the benefit of the community. Spain in her poverty was a continual drain upon the colonies; and all the revenue that could be raised from them on the plan of a jealous and restricted commercial policy, was ever urgently called for by the mother country. So much only was kept back as was necessary to defray the expenses of the local government, and satisfy the demands of a corrupt and rapacious colonial administration. In proportion as the exigencies of Spain increased, a still greater relaxation in the government of the colonies took place. More supplies were wanted by the mother country, in consequence of the growing expense to which she was put by the French invasion. ${ }^{57}$

The colonies are depicted as hopelessly exposed and being at the mercy of the metropolitan "greed". The Spanish motherland itself was, according to the Robertson brothers, affected by many structural evils starting with an "imbecile king", "a corrupt nobility" as well as "a powerful, bigoted, and tyrannical priesthood". ${ }^{58}$ Another anecdote shows, for instance, how Francia did not accept any gifts at all. Rengger describes the scene of their first official meeting with Dr. Francia, when the dictator noticed a print representing Napoleon Bonaparte Rengger was carrying among his documents. ${ }^{59}$

He took it up, and examined it with great interest, when I told him whose likeness it was. He then began conversing familiarly upon the affairs of Europe, with which he seemed to be better acquainted than I could have supposed. ${ }^{60}$

Then, Rengger continues:

On coming away, I left the portrait of Buonaparte on his table, thinking he would have been glad to have it; he sent it after me by an officer, with 
an order to ask the price I set on it. As I did not wish to accept money for it, it being of little value, and as the Dictator had made it a rule never to receive a present, the miniature remained in my possession. ${ }^{61}$

For Rengger and Longchamp it was probably important to point out this character trait, because it indicated a discrepancy with respect to the collective image of former colonial officeholders, and because it compensated other more problematic traits of his character. Another way the Swiss found to underline his virtues, was the rejection of nepotism as the next example demonstrates:

Two of his nephews, officers in the regular troops at the commencement of the revolution, were the first whom he dismissed the service, after he had become Dictator, for no other reason than the fear he had that they might presume upon their relationship. ${ }^{62}$

This raises the question whether these measures were straightforward steps to improve the young national administration, or rather for the sake of selling an image of an incorruptible and selfless ruler. There were nonetheless also alternative versions of Francia's “ethos". English traveller Alexander Caldcleugh (1795-1858) pointed out in his 1825 travelogue that one of Francia's first steps after becoming dictator was to appoint two of his nephews as personal secretaries; i.e. a prime example of nepotism. ${ }^{63}$

The narrative at the basis of this article is simple: the independence from Spanish rule and the creation of new nations no longer subject to the distant Crown was the starting point also for the elimination of the many evils of state administration, no matter whether judicial, executive, commercial or ecclesiastical ones. The transparency of a system with control instances, with officeholders committed to an ethos now obliged to the new republic, to be literally understood as a "common wealth"where the nation's welfare was set above particular interests-was a revolutionary idea.

However, the struggle for emancipation became one among the young republics, also against each other, and in some cases actual civil wars. The Robertson brothers saw in those struggles a consequence of the combination between some individuals' seek for "their own aggrandisement at the expense of the public weal" and "the system of corrupt government and narrow policy, left as an heirloom [...] by the bigoted mother-country to her oppressed offspring in the colonies". ${ }^{64}$ Moreover, despite praising 
the dictator's rectitude, the same authors perceived the side effects of the authoritarian remedy against corruption to be as follows: "You will see a simple, fine, confiding people, that had been comparatively happy under the régime of Old Spain reduced to wretchedness and imbecility, under the iron rule of one who has yet the audacity to style himself a 'patriot'". 65

If we roughly sketch the main lines on the account about Francia, we may recognise a pattern based on the assumption of juxtaposition between the different notions of honour. The corrupt judge claimed an obsolete kind of honour, corrupted itself by bigotry and hypocrisy, but based on the judge's belonging to a particular privileged estate or caste. This provides a deep contrast with Francia's honour defined by his radical and intransigent behaviour, despite his Creole background.

\section{General Juan Manuel De Rosas: “...A Man Whose Crimes Have no Redeeming Quality"66}

It is probably no exaggeration to claim that early post-colonial Spanish America became the home of several "iron rules". Particularly worthy of mention is that of General Juan Manuel de Rosas, who was twice Governor of Buenos Aires-between 1829 and 1832 and again, with the sum of public power, between 1835 and 1852. Rosas was born in Buenos Aires in 1793 to a family of wealthy estancieros devoted to cattle-breeding. After his marriage, he abandoned the parental estancia to become independent. Thus, he built up his prestige upon the image of a self-made man. ${ }^{67}$ Charles Darwin was bedazzled by Rosas, and his reputation of an efficient gaucho leader and politician, when they met in $1833 .{ }^{68}$

His rule was characterised by a high degree of political violence against dissidents, mainly Unitarians who fought for a centralist Argentine nation-state, opposed to the Federalists. This political violence was mostly perpetrated through the members of the armed wing of the Sociedad Popular Restauradora, the so-called mazorca, literally "corn cob", sometimes referred to by means of a macabre pun as más-horca, i.e. "more gibbets". ${ }^{69}$ The governor's involvement in belligerences such as the Anglo-French Blockade and the Uruguayan Civil War was the prompt for many pamphlets and articles about Rosas and his regime, circulating between Western Europe and South America, taking sides either in favour or against him. 
José Rivera Indarte (1814-1845) was an Argentine poet and journalist who had originally supported General Rosas, but later changed sides and became his detractor. ${ }^{70}$ In 1843 , he published the pamphlet Rosas y sus opositores where he scrutinised the regime under different points of view. References to corruption are recurrent, although he points out both Rosas' corruption of morals and the political one, resulting in an enrichment of the dictator's wealth as well as that of his partners. Natalia Volosin has recently used the term "kleptocracy" to refer to the corruption, misappropriation and extortion practices between 1827 and the end of Rosas' regime. ${ }^{71}$ As a matter of fact, Rivera Indarte criticised the misappropriation of the pensions for war victims.

The financial system of Buenos Aires became one of scandalous theft. We will be very brief on this point for now, because we have something to say when we deal with the pensions system in its current administration. The compensation decreed by the Court for those who had suffered losses in the war, was for him [General Rosas] and his main supporters a source of personal wealth. The damages of his adversaries had been immense, but he ordered them to be appraised very low, and did so in such a way that, desperate for the holders to be able to obtain the payment of their tickets or liquidations, they alienated them to Rosas' agents. ${ }^{72}$

The author claimed that close collaborators of Rosas, such as Minister Agustín Garrigós, profited from the illicit enrichment. In this particular case, it derived from the expropriation of the exiled physician Juan José Montes de Oca:

Garrigós, a miserable clerk, with a salary at its best of eight thousand paper pesos, today boasts a scandalous fortune. His farms are many and of great value. The house in which he lives richly furnished, with part of the menage stolen from Dr. Montesdeoca [sic], is accusing his infamous thefts, and the corruption of the tyrant who tolerates them. ${ }^{73}$

The dictator's camarilla and his close collaborators are, in fact, according to Historian Jürgen Osterhammel, a keystone for the perpetuation of dictatorial rule in general. ${ }^{74}$ Rivera Indarte, who took sides for the sieged Montevideans and their former President José Fructuoso Rivera (17841854), compared the latter with Rosas in terms of wealth, providing a Manichaean dichotomy: 
General [Fructuoso] Rivera, in spite of everything Rosas says, is poor in fortune, while his pure accuser [General Rosas] lives in a non-inherited opulence, for which he does not work and which always increases. General Rivera is frugal and has simple habits. The cutthroat Rosas, his slanderer, is vicious, corrupt and lavish. These few words demonstrate more truths than a justification of many pages. ${ }^{75}$

Then, Rivera Indarte presented General Rosas as the exception within a tradition of honourable state servants since the foundation of independent Argentina:

Since there has been an independent [Argentine] government, none of the distinguished men who have presided over the State have been awarded extraordinary prizes for it; but Rosas, had the war ended with Lavalle, demanded 725,000 pesos, which, reduced to silver, brought 130,000 patacones, for the damages he had received in the war. What were these damages? Three to four thousand heads [of cattle] that General Lavalle took from his estancia to supply the town of Buenos-Ayres and that were sold for a commission to the highest bidder, depositing the product in the Bank where Rosas found it. ${ }^{76}$

Thus, Rosas was reimbursed for a loss which had not happened, Rivera Indarte claims. The dissident portrays an image of utmost greed, pride, cruelty and unscrupulousness, but where the Spanish colonial past no longer plays any particular role. There might be more than one reason for this. Since Rivera Indarte was born in 1814, he did not experience colonial rule himself, although he must have learned the history of preindependent Argentina at school and in the sharing of collective national memory.

As a landowner and considering the ongoing war on the southern border against the indigenous people, under Rosas' rule land was the main form of property and also the main source of income. Thus, land grants and confiscation were common policies to reward his supporters and punish his enemies. ${ }^{77}$ The practices of misappropriation perpetrated by the rosist regime were also perceived by foreigners. Swiss mercenary and adventurer Heinrich Trachsler claimed in his travelogue:

The good Argentines might have retained Spanish sovereignty in his place, for they would certainly not have gone any worse under this [colonial] 
government than they do now under the federal government and under that rough, uneducated gaucho general Rosas, and his creatures. ${ }^{78}$

Trachsler, whose witness might be questioned since he left South America already in 1835 , i.e. at the very beginning of Rosas' second (and definitely more ruthless) tenure, mentions the arbitrary arrests and executions as well as the confiscations of property belonging to the Unitarians. Therefore, Rosas' brutality makes appear the independence from Spain vain.

An anonymous British citizen residing in Montevideo during the siege addressed a public writing to Lord Aberdeen in 1844, the British Secretary of State for Foreign Affairs. The text, which assumes the form of a complaint in front of a global audience, is permeated by a sentiment of indignation. Although one can assess corruption to be a lesser crime compared to the assassinations, tortures, rapines and acts of blasphemy, the author provides a quotation from an English language newspaper published in Montevideo-The Britannia- stating:

The national hospitals for the sick, for the insane, for the houseless poor and abandoned orphans, have been suppressed; and the funds belonging to them, appropriated by the Government to itself under the pretext of an engagement, never fulfilled, to provide for their support. ${ }^{79}$

The critique of corruption is combined with the pursuit of empathy (or compassion) by emphasising the precarious condition of sick people and foundlings under Rosas' rule. Such comments were relevant because the French intervention in the River Plate in favour of the besieged Montevideans and against General Rosas had much of humanitarian reasons, aimed at defending a supposed (French) enlightened heritage embodied by Rosas' opponents. ${ }^{80}$ In other words, the terrible news from the River Plate inculcated sentiments of solidarity and compassion which, in terms of the history of emotions, had started with abolitionist ideas half a century before. ${ }^{81}$

In 1845, Argentine anti-rosist dissident Domingo Faustino Sarmiento (1811-1888) published what became a lieu de mémoire of Latin American literature. Facundo was a public denunciation of General Rosas, articulated through the dichotomy of civilisation-embodied by the city and its enlightened heritage-and barbarism, i.e. the countryside with its gauchos and their brutal manners. Following that same dichotomy, 
Sarmiento refers to Bernardino Rivadavia (1780-1845), who was former minister and President of the United Provinces of the Río de la Plata until 1827, and a most efficient visionary and tireless reformer as well as a fellow Unitarian, like the author. Meanwhile, Rosas is positioned as his ruthless counterpart:

[T] he Banco Nacional is an institution so deeply rooted that it has saved society from the misery to which the tyrant [Rosas] would have led it. Above all, however fantastic and inopportune that great system-toward which all the peoples of America are now heading and hurrying-might have been, at least it was easy and tolerable for people; and however much men without conscience may scream about him every day, Rivadavia never spilled a drop of blood or destroyed anyone's property, descending voluntarily from the luxury of the presidency to the noble, humble poverty of the exile. Rosas, who so slanders him, would drown in the lake formed by all the blood he himself has spilled; and the forty million pesos from the national treasury and the fifty from private fortunes that Rosas has consumed in ten years to support the interminable war that his brutalities have ignited, in the hands of that fatuous dreamer, Rivadavia, would have been turned into canals for navigation, great, built-up cities, and many establishment for public utility. ${ }^{82}$

The accusation of maladministration is performed on the basis of a Manichaean comparison. Emotions of deep anger and contempt, not only for General Rosas and the eponymous caudillo Juan Facundo Quiroga, but for the entire countryside unveil a rather arrogant and elitist stance. The Enlightenment discourse enforced arguments of moral superiority with bodily and racist components. In the words of historian Margrit Pernau: "Feelings were an indicator of a present level of development that divided the world up between the civilised, the decadent and the barbaric; but, at the same time, feelings were themselves the basis of all development". 83

The terms "corruption" and "corrupt" are commonly used in a generic sense, not just referring to the illicit and shameless accumulation of tangible goods, but as a denomination for the dictator and his thugs' malicious and infamous nature. In 1849, a collection of newspaper articles appeared in Montevideo. This time, the expropriations by Rosas show up as prominently as in the title, flanking the narrative of sanguinary crimes. 
Although, as we have already said in our articles on Rosas' robberies called confiscations, the money that was deposited in his cash box, as a result of them [the robberies/confiscations], only represents a minimal part of the values confiscated, however, in his states [...] you can see the enormous amounts that were deposited belonging to [Lucas] Gonzalez, and calculate the immense capital that Rosas stole from his family: as they deposited other very large [sums], belonging to his nephew, Mr. Borbon, a Buenos Aires citizen, whose property was also confiscated, and who also saved his life by hiding and taking refuge in Montevideo. 84

Personal enrichment seems to thus be the dictator's sole purpose. Nevertheless, considering the amount of power he was bestowed within 1835, one could question whether those confiscations were really illegal and, therefore, whether they can be considered phenomena of corruption. Here approaches from legal history, moral philosophy and the history of emotions might provide different answers.

\section{CONCLUSIONS}

If we resume the idea of colonial corruption as a combination of the opportune distance from the motherland as supreme authority and the officeholders' passions, vices and pursuits of prestige, we will easily conclude that after the emancipation the latter aspect remained. With regard to the "pathogenic" interpretation of corruption, we have already remarked how Villarroel resorted to medical metaphors. This means a rationalistic view, typical for the Enlightenment and positivism and linked to an idea of progress. The same is true for Reverend William Robertson who speaks of an “infection”, and for Franz Kottenkamp's "antidote" (German Gegenmittel). In other words: corruption is a solvable problem if the adequate medicine is applied. This is also what Villarroel wants to provide: solutions, therapies and mitigations. On the opposite side, the Robertson brothers-who adopt merely a descriptive and judging attitude-used a biblical pattern to describe the episode of judicial corruption. This might suggest a definitely fatalistic stance, where the emplotment (Hayden White) ${ }^{85}$ is at least partially provided by divine providence and where the advocate's virtues under the corrupt colony succumb to his love of power, once he had become dictator. This idea of irreversibility is also expressed through terms such as "heirloom" and "offspring", as if corruption would be part of the new nations' 
"genetic material", provided by the mother country. Thus, the dichotomy suggested by Christoph Rosenmüller for early modern Spanish Americai.e. innate versus performative corruption — seems to find its continuity as a pattern of interpretation at the beginning of the nineteenth century. ${ }^{86}$

With the dictator of Paraguay, and his depiction by contemporaries, we meet the anticipation of a topos-generally accredited to early twentieth century (fascist) dictators-about a century in advance. ${ }^{87}$ Thus, the "incorrupt" Dr. Francia enjoyed an image very much shaped after Maximilien Robespierre (1758-1794), l'incorruptible. ${ }^{88}$ However, with Juan Manuel de Rosas and his judgement by contemporaries, it seems that the topos of the incorrupt dictator was complemented by that of the "corrupt tyrant" Rosas, for whose practices Spanish late colonial corruption did not provide any inspiration. As already remarked, pamphlets, articles and essays on rosist corruption lacked in references to the ages of the corrupt colony-except for Trachsler's travelogue. This is due to two reasons. Firstly, the corruption under Rosas was systematic in the sense that it permeated the entire state administration and was even an instrument of oppression, while the practices under Spanish rule have to be regarded as a sort of organic or systemic corruption. Furthermore, there was no need to resort to such a remote antithesis as Spaniards versus patriots, since Argentina suffered, since the 1820s, from a never-ending civil war, with the potential of removing late Bourbon corruption practices from collective memory. Secondly, Rosas' corruption was regarded as a lesser evil compared to the horrendous crimes he perpetrated by means of his militia, as reported by Rivera Indarte in his famous Tablas de Sangre ("Blood Tables"). This was a gruesome, meticulous-though exaggerated-palimpsest of Rosas' killings, which reached Europe, too. In terms of emotions, the corruption of Rosas and his followers is backed by the use of blank terror, a sentiment which takes us back to the French revolutionary grande terreur, to Robespierre and the obsessive search for virtue.

If "corruption" can be semantically deconstructed in other notions such as favouritism, patronage, venality and bribery, while on the antonymous side terms like integrity, virtue and selflessness are available, ${ }^{89}$ an analysis on the basis of emotions shows an analogous opposition. If we count for instance greed, pride and arrogance as the underlying sentiments of corruption, we might count honour, justice and equality on the other side. There is, however, one sentiment which can be located both on the side of corruption and of its mitigation. Alexis de Tocqueville 
(1805-1859) considered envy a distinguished democratic sentiment since it mobilises lower classes against the elites. ${ }^{90}$ Austrian-German sociologist Helmut Schoeck stated in his acclaimed work Envy: A Theory of Social Behaviour that envy had the potential to tame the tyrant's absolute power too, thus admitting the positive sides of this controversial sentiment. ${ }^{91}$ Following this line of thought, envy may be attributed the faculty to fight corruption as well, or it makes wealthy and successful colonial officers appear as corrupt in the eyes of invidious contemporaries. This consideration becomes particularly patent in Tanja Bührer's contribution to this volume, about the nabobs returning to Britain. It is perhaps time to consider corruption, in all its complexities, as a corruption of particular emotions. On a global scale, emotions allow us to duly relativise and recontextualise the origins of corruption and corruptionfighting measures, whether in the form of a society losing fear for the sake of opposing a scoundrel government or questioning the source of overwhelming wealth and luxury.

Acknowledgements The author would like to thank the Swiss National Science Foundation for providing the grant for the open access publication (grant number P2BC-1_200622).

\section{Notes}

1. William Robertson, "The History of America," in The Works of William Robertson (London, 1817), 4:116.

2. John H. Elliott, Imperial Spain 1469-1716 (London: Penguin Books, 1963), 174-75; Anthony McFarlane, "Political Corruption," in Political Corruption in Europe and Latin America, ed. Walter Little and Eduardo Posada-Carbó (Basingstoke, London: Macmillan/St. Martin's Press, 1996), 43-53; see also the chapter by Bartolomé Yun-Casalilla within this volume.

3. See Anubha Anushree's chapter within this volume with regard to honour and sympathy.

4. Michel Delon, "L'éveil de l'âme sensible," in Histoire des émotions, ed. Alain Corbin (Paris: Seuil, 2016), 2:11-42; William M. Reddy, The Navigation of Feeling: A Framework for the History of Emotions (Cambridge: Cambridge University Press, 2001), 141-72; Mónica Bolufer Peruga, "En torno a la sensibilidad dieciochesca: discursos, prácticas, paradojas," in Las mujeres y las emociones en Europa y América. Siglos XVII-XIX, ed. María 
Luisa Candau Chacón (Santander: Editorial Universidad de Cantabria, 2016).

5. Jens Ivo Engels, "Revolution und Panama. Korruptionsdebatten als Systemkritik in Frankreich vom 18. Jahrhundert bis zur Dritten Republik," in Geld - Geschenke - Politik. Korruption im neuzeitlichen Europa, ed. Jens Ivo Engels, Andreas Fahrmeir and Alexander Nützenadel (München: Oldenbourg, 2009), 144-57.

6. McFarlane, "Political Corruption," 47.

7. Robert Sparling, "Montesquieu on Corruption: Civic Purity in a PostRepublican World," in On Civic Republicanism. Ancient Lessons for Global Politics, ed. Geoffrey C. Kellow and Neven Leddy (Toronto: University of Toronto Press, 2016).

8. For a concise conceptual history of corruption, see Jens Ivo Engels, Die Geschichte der Korruption. Von der Frühen Neuzeit bis ins 20. Jahrhundert (München: S. Fischer, 2014), 165-71.

9. McFarlane, "Political Corruption," 48.

10. Ibid., 41-43; Christoph Rosenmüller, "Corruption, Abuse, and Justice in the Iberian Empires," in Corruption in the Iberian Empires. Greed, Custom, and Colonial Networks, ed. Christoph Rosenmüller (Albuquerque, NM: University of New Mexico Press, 2017), 1-12; Regina Grafe and Alejandra Irigoin, "A stakeholder empire: the political economy of Spanish imperial rule in America," The Economic History Review 65, no. 2 (April 2012): 631, https://doi.org/10.1111/j.1468-0289.2010. 00581.x; Christoph Rosenmüller, Patrons, Partisans, and Palace Intrigues. The Court of Colonial Mexico, 1702-1710 (Calgary: University of Calgary Press, 2008), 29-32.

11. See for instance also John M. Niles, History of South America and Mexico (Hartford: H. Huntington, 1838), 1:116.

12. Robertson, "History of America", 107-108; Alexander von Humboldt, Essai politique sur le Royaume de la Nouvelle-Espagne (Paris: F. Schoell, 1811), 1:119.

13. Lutz Raphael, "Freiheit und Wohlstand der Nationen. Alexander von Humboldts Analysen der politischen Zustände Amerikas und das politische Denken seiner Zeit," Historische Zeitschrift 753, no. 3 (1995).

14. Wolfgang U. Eckart, Geschichte, Theorie und Ethik der Medizin (Berlin, Heidelberg: Springer, 2013), 159.

15. Ute Frevert, Vergängliche Gefühle (Göttingen: Wallstein Verlag, 2013), 12; Jan Plamper, The History of Emotions. An Introduction (Oxford: Oxford University Press, 2015), 80-83.

16. Pierangelo Catalano, "Consolato e dittatura: L' 'esperimento' romano della Repubblica del Paraguay (1813-1844)," in Dittatura degli antichi e dittatura dei moderni, ed. Giovanni Meloni (Roma: Editori riuniti, 1983). 
17. John Lynch, "Spanish American Independence in Recent Historiography," in Independence and Revolution in Spanish America: Perspectives and Problems, ed. Anthony McFarlane and Eduardo Posada-Carbó (London: Institute of Latin American Studies, 1999), 36.

18. José Carlos Chiaramonte, La Ilustración en el Río de la Plata: Cultura eclesiástica y cultura laica durante el Virreinato (Buenos Aires: Puntosur, 1989); Gabriel Entin, "Les formes de la république: monarchie, crise et révolution au Rio de la Plata," in Les Empires atlantiques des Lumières au libéralisme (1763-1865), ed. Federica Morelli, Clément Thibaud and Geneviève Verdo (Rennes: Presses Universitaires de Rennes, 2009); Noemí Goldman, Historia y lenguaje: los discursos de la Revolución de Mayo (Buenos Aires: Centro Editor de América Latina, 1992); O. Carlos Stoetzer, El pensamiento político en la América española durante el periodo de la emancipación (1789-1825) (Madrid: Instituto de Estudios Políticos, 1966); id., "The Importance of Classical Influences during the SpanishAmerican Revolutions," Jabrbuch für Geschichte von Staat, Wirtschaft und Gesellschaft Lateinamerikas 30, no. 1 (1993), https://doi.org/10.7788/ jbla-1993-0109.

19. Douglas Botting, Alexander von Humboldt, trans. Annelie Hohenemser (München: Prestel, 2012), 242.

20. Alexander von Humboldt, Political Essay on the Kingdom of New Spain, trans. John Black (Cambridge: Cambridge University Press, 2014), 1:138, https://doi.org/10.1017/CBO9781139923897; Humboldt, Essai politique, 1:103: "Le premier choix des personnes auxquelles la cour a confié les places importantes d'intendans ou de gouverneurs de province, a été très heureux. Parmi les douze qui administroient le pays en 1804, il n’y en avoit pas un seul que le public accusât de corruption ou d'un manque d'intégrité".

21. Ursula Goetzl, "Alexander von Humboldt als Geschichtsschreiber Amerikas” (PhD diss., Ludwig-Maximilians-Universität München, 1966), 58 .

22. Myron Echenberg, Humboldt's Mexico: In the Footsteps of the Illustrious German Scientific Traveller (Montreal: McGill-Queen's University Press, 2017), 25-33.

23. Ottmar Ette, "Transatlantic Perceptions: A Contrastive Reading of the Travels of Alexander von Humboldt and Fray Servando Teresa de Mier," Dispositio 17, no. $42 / 43$ (1992): 181.

24. Franz Kottenkamp, Der Unabhängigkeitskampf der spanischamerikanischen Colonien (Stuttgart: Literatur-Comptoir, 1838), 14: “Die Regierung selbst erlitt durch diese Zusammensetzung ihrer Verwaltung bedeutenden Schaden in ihren Einkünften. In einer reinen Bureaukratie, wo wegen der Entfernung vom Mittelpunkte eine strenge Controlle unmöglich ist, ergiebt sich Bestechung als nothwendige Folge. Außerdem 
hatten alle Spanier schnelle Bereicherung und Rückkehr in's Mutterland vor Augen, Beweggründe, die Mittel um so eifriger zu benutzen, welche dieselben schnell befördern konnten".

25. Luis Villoro, "Rousseau en la Independencia mexicana," Casa del Tiempo 7 (2005); Gabriel Torres Puga, "Rousseau en Nueva España: presencia y recepción antes de 1808," in Rousseau en Iberoamérica: Lecturas e interpretaciones entre Monarquía y Revolución, ed. Gabriel Entin (Buenos Aires: Sb editorial, 2018).

26. Virgina Gil Amate, "Hipólito Villarroel: una mirada ilustrada sobre la Ciudad de México," Tema y variaciones de literatura: México prehispánico y colonial: miradas contemporáneas 32 (2009).

27. For a concise biography of Hipólito Villarroel see Anel Hernández Sotelo, "Hipólito Villarroel y las enfermedades políticas de la Nueva España," Boletin Cultural. Órgano Informativo y Cultural de la Escuela Nacional de Antropología e Historia 18 (2003).

28. Carlos María de Bustamante, ed., México por dentro y fuera, bajo el gobierno de los Vireyes (México: En la imprenta del ciudadano A. Valdez, 1831), 36-40.

29. Pierre-Yves Beaurepaire, "The View from Below: The 1789 cabiers de doléances," in The Oxford Handbook of the French Revolution, ed, David Andress (Oxford: Oxford University Press, 2015), 156-60.

30. Guillaume Mazeau, "Émotions politiques," in Histoire des émotions, ed. Alain Corbin (Paris: Seuil, 2016), 2:98-142; Emmanuel Fureix, "Les émotions protestataires," in Histoire des émotions, ed. Alain Corbin (Paris: Seuil, 2016), 2:299-321; Reddy, Navigation of Feeling, 193.

31. Reddy, Navigation of Feeling, 188.

32. Michael Zeuske, "The French Revolution in Spanish America: With Some Reflections on Manfred Kossok as Marxist Historian of 'Bourgeois Revolutions'," Review 38, no. 1/2 (2015): 118.

33. According to Clément Thibaud, the relevance of enlightened thought for the revolution in Colombia and Venezuela should be relativised. Clément Thibaud, Libérer le Nouveau Monde. La fondation des premières républiques hispaniques (Colombie et Venezuela, 1780-1820) (Bécherel: Les Perséides, 2017), 158-61.

34. Jeremy Adelman, Sovereignty and Revolution in the Iberian Atlantic (Princeton, NJ: Princeton University Press, 2006), 146.

35. On the significance of love for Spanish colonial administration see Alejandro Cañeque, "The Emotions of Power: Love, Anger, and Fear, or How to Rule the Spanish Empire," in Emotions and Daily Life in Colonial Mexico, ed. Javier Villa-Flores and Sonya Lipsett-Rivera (Albuquerque, NM: University of New Mexico Press, 2014), 92-100 and 106-13.

36. Miguel Ángel Vásquez Meléndez, "Los ceremoniales en la construcción de la imagen del rey amable (Nueva España, 1789-1791)," in Amor e 
historia. La expresión de los afectos en el mundo de ayer, ed. Pilar Gonzalbo Aizpuru (México D.F.: El Colegio de México, 2013), 370-75.

37. On the emotional uncertainty of Creoles in late-colonial New Spain see Matthew D. O'Hara, “Anxiety, the Future, and Mexican Independence," in Emotions and Daily Life in Colonial Mexico, ed. Javier Villa-Flores and Sonya Lipsett-Rivera (Albuquerque, NM: University of New Mexico Press, 2014), 199-202.

38. Kottenkamp, Der Unabhängigkeitskampf, 19-20: “Ein Richter aus Aragon entschied anders wie der aus Castilien, der wieder von der Entscheidung eines Andern aus Grenada [sic] abwich u. s. w. Somit gesellte sich Unsicherheit des Rechtes und des Eigenthums zu der übrigen Unbill, welche die Creolen von dem Mutterlande zu erleiden hatten. Das einzige Gegenmittel lag in der Gewalt des Vicekönigs, welcher in höchster Instanz den Spruch der Gerichte vernichten konnte, und somit die letzte unumschränkte Auslegung und Anwendung der Gesetze zu seiner übrigen Gewalt hinzufügte. Die Folge derselben mag man sich leicht vorstellen. Unter den Creolen herrschte die allgemeine Meinung, kein Prozeß gegen eingeborene Spanier könne von ihnen ohne größere Bestechung gewonnen werden".

39. This biographical sketch is based on Julio César Chaves, El Supremo Dictador. Biografía de José Gaspar de Francia (Madrid: Ediciones Atlas, 1964). See further Moisés Prieto, “«History’s So Strong». The Topos of Historia Magistra Vitae and the Re-Discovery of Dictatorship in Latin America," History of Humanities 5, no. 1 (2020): 230-37, https://doi. org/10.1086/707700.

40. On the practice of power under Francia's rule and the meaning of “dictating" in this particular context, see Nora Esperanza Bouvet, Poder $y$ escritura. El doctor Francia y la construcción del Estado paraguayo (Buenos Aires: Editorial Universidad de Buenos Aires, 2009).

41. Barbara Potthast and Ignacio Telesca, “¿Nueva jurisprudencia o pragmatismo político? Paraguay y su lucha por mantener la independencia," in Juristas de la independencia, ed. José María Pérez Collados and Samuel Barbosa Rodrigues (Madrid: Marcial Pons, 2012).

42. For this chapter, I will use the English translation of 1827.

43. Leila Gómez, Iluminados y tránsfugas. Relatos de viajeros y ficciones nacionales en Argentina, Paraguay y Perú (Frankfurt/Madrid: Iberoamericana Vervuert, 2009), 134-35.

44. Johann Rudolph Rengger and Marcelin Longchamp, The Reign of Doctor Joseph Gaspard Roderick de Francia in Paraguay Being an Account of a Six Years' Residence in That Republic (London: Thomas Hurst, Edward Chance \& Co., 1827), 6-7. 
45. Charles Jones, "Robertson, John Parish," Oxford Dictionary of National Biography, accessed May 24, 2020, https://doi.org/10.1093/ref:odnb/ 23805.

46. Günter Kahle, "Ein südamerikanischer Diktator, Dr. Francia von Paraguay, im Spiegel der europäischen Geschichtsschreibung," Saeculum 15 (1964): 254, https://doi.org/10.7788/saeculum.1964.15.jg.249.

47. John P. Robertson and William P. Robertson, Four Years in Paraguay (Philadelphia: Carey \& Hart, 1838), 2:27-29.

48. Thomas Carlyle, "Dr Francia," in Critical and Miscellaneous Essays: Collected and Republished by Thomas Carlyle (London: Chapman and Hall, 1847), 4:282-83.

49. Rosenmüller, "Corruption, Abuse, and Justice," 4. This corresponds to Natalie Z. Davis' remarks on sixteenth-century France. Natalie Zemon Davis, The Gift in Sixteenth-century France (Madison: University of Wisconsin Press, 2000), 87.

50. Pilar López Bejarano, “«Empapelar» al enemigo. El recurso a los procesos judiciales como estrategia de la acción política (Nueva Granada entre colonia y república)," in Justicias, agentes y jurisdicciones. De la Monarquía Hispánica a los Estados Nacionales (España y América, siglos XVI-XIX), ed. Elisa Caselli (Madrid, México: Fondo de Cultura Económica de España/Fondo de Cultura Económica, 2016), 96-99.

51. Valentina Bravo-Olmedo, "«Le ofreció dinero para que no lo demandase». Justicia negociada y género en prácticas de resolución de conflictos por pensión de alimentos. Chile Central, 1788-1840," Trashumante. Revista Americana de Historia Social 11 (January-June 2018): 159-60, https:// doi.org/10.17533/udea.trahs.nl la07; Bianca Premo, "Lo extrajudicial. Between court and community in the Spanish empire," in The Uses of Justice in Global Perspective, 1600-1900, ed. Griet Vermeesch, Manon van der Heijden, and Jaco Zuijderduijn (London: Routledge, 2019), 187-89.

52. Bianca Premo, The Enlightenment on Trial. Ordinary Litigants and Colonialism in the Spanish Empire (Oxford: Oxford University Press, 2017), 3 (original emphasis).

53. Ibid., 185.

54. Ute Frevert, Emotions in History - Lost and Found (Budapest, New York: Central European University Press, 2011), 40-42.

55. Christian Büschges, "«Las leyes del honor». Honor y estratificación social en el distrito de la audiencia de Quito (siglo XvIII)," Revista de Indias LVII, no. 209 (1997): 57-62, https://doi.org/10.3989/revindias.1997. i209.795.

56. Reddy, Navigation of Feeling, 203; id., "Sentimentalism and Its Erasure: The Role of Emotions in the Era of the French Revolution," The Journal of Modern History 72, no. l (2000): 145, https://doi.org/10.1086/ 315931 . 
57. John P. Robertson and William P. Robertson, Letters on Paraguay (London: John Murray, 1838), 1:22.

58. Ibid., 1:20.

59. For a description of this scene in terms of the history of emotions see Moisés Prieto, "Dictadura y sentimiento: las emociones en un relato europeo sobre el Doctor Francia, Supremo Dictador del Paraguay," Iberoamericana 18, no. 69 (September-December 2018): 136-38, https://dx.doi.org/10.18441/ibam.18.2018.69.127-150.

60. Rengger and Longchamp, The Reign of Doctor Joseph Gaspard Roderick de Francia, 40.

61. Ibid., 42.

62. Ibid., 207.

63. Alexander Caldcleugh, Travels in South America, During the Years 181920-21 (London: John Murray, 1825), 1:130-31.

64. Robertson and Robertson, Letters on Paraguay, 1:89-90.

65. Ibid., 1:92-93.

66. Rosas and some of the Atrocities of his Dictatorship in the River Plate (London: Simmons and Clowes, 1844), 6.

67. John Lynch, Argentine Caudillo. Juan Manuel de Rosas (Oxford: SR Books, 2001), 14; id., Argentine Dictator: Juan Manuel de Rosas 18291852 (Oxford: Clarendon Press, 1981), 14; Raúl O. Fradkin and Jorge Gelman, Juan Manuel de Rosas. La construcción de un liderazgo politico (Buenos Aires: Edhasa, 2015), 45-50.

68. Lynch, Argentine Dictator, 3-5.

69. Fradkin and Gelman, Juan Manuel de Rosas, 301-305; Lynch, Argentine Dictator, 201-46.

70. Gabriel Di Meglio, ¡Mueran los salvajes unitarios! La Mazorca y la politica en tiempos de Rosas (Buenos Aires: Editorial Sudamericana, 2007), 58.

71. Natalia A. Volosin, Corruption in Argentina. Towards an Institutional Approach (London: Routledge, 2019), 57-58; Lynch, Argentine Caudillo, 129.

72. José Rivera Indarte, Rosas y sus opositores (Montevideo: Imprenta del Nacional, 1843), 221: “El sistema financiero de Buenos Aires se convirtió en esa administracion en uno de escandaloso latrocinio. Seremos por ahora muy breves en este punto, porque algo tenemos que decir cuando tratemos del sistema rentístico en su actual administracion. Las indemnizaciones decretadas por la Sala para los que hubiesen sufrido pérdidas en la guerra, fué para él [General Rosas] una fuente de riqueza personal y para sus principales partidarios. Los menoscabos de sus adversarios habian sido inmensos, pero él los mandó evaluar muy bajo, é hizo de modo, que desesperados los tenedores de poder conseguir el pago de sus boletos ó liquidaciones, los enagenaron á los agentes de Rosas”. 
73. Ibid., 308: "Garrigós, misero oficinista, con un sueldo en su mejor época de ocho mil pesos papel, ostenta hoy una fortuna escandalosa. Sus fincas son muchas y de crecido valor. La casa en que vive ricamente amueblada, con parte del menage robado al Dr. Montesdeoca [sic], está acusando sus infames latrocinios, y la corrupcion del tirano que los tolera".

74. Jürgen Osterhammel, The Transformation of the World: a global history of the nineteenth century, trans. Patrick Camiller (Princeton, NJ: Princeton University Press, 2014), 576.

75. Rivera Indarte, Rosas y sus opositores, 105: "El general [Fructuoso] Rivera, apesar de todo lo que dice Rosas, es pobre de fortuna, mientras su puro acusador [General Rosas] vive en una opulencia no heredada, para la que no trabaja y que siempre se aumenta. El General Rivera es frugal y de costumbres sencillas. El degollador Rosas su calumniador es vicioso, corrompido y fastuoso. Estas pocas palabras demuestran mas verdades que una justificacion de muchas paginas".

76. Ibid., 301: "Desde que existe gobierno independiente, á ninguno de los hombres distinguidos que han presidido el Estado, se han acordado premios extraordinarios por ello; pero Rosas se hizo dar acabada la guerra con Lavalle 725 mil pesos, que reducidos á plata importaron 130 mil patacones por los perjuicios que había recibido en la guerra. ¿Cuales éran estos perjuicios? Tres á cuatro mil cabezas que de su estancia sacó el General Lavalle para abastecer el pueblo de Buenos-Ayres y que se vendieron por una commission al mas alto postor, depositando el producto en el Banco donde lo encontró Rosas".

77. Lynch, Argentine Dictator, 64-69; Silvia Ratto, “¡Finanzas públicas o negocios privados? El sistema de racionamiento del negocio pacífico de indios en la época de Rosas," in Caudillismos rioplatenses. Nuevas miradas a un viejo problema, ed. Noemí Goldman and Ricardo Salvatore (Buenos Aires: Eudeba, 1998), 259-64.

78. Heinrich Trachsler, Reisen, Schicksale und tragikomische Abenteuer eines Schweizers (Zürich: Verlag von Heinrich Trachsler, 1839), 698-99: “[Die] guten Argentiner hätten an seiner Statt eben so gut die spanische Oberherrschaft beibehalten können, denn sie wären unter dieser Regierung gewiß nicht übler gefahren, als jetzt unter den Föderalen und unter diesem rohen, ungebildeten Gauchosgeneral Rosas, und seinen Kreaturen".

79. Rosas and some of the Atrocities, 32.

80. Edward Shawcross, France, Mexico and Informal Empire in Latin America, 1820-1867. Equilibrium in the New World (Cham: Palgrave Macmillan, 2018), 60.

81. Frevert, Emotions in History, 200-201; Bertrand Taithe, "Empathies, soins et compassions: les émotions humanitaires," in Histoire des émotions, ed. Jean-Jacques Courtine (Paris: Seuil, 2017), 3: 365-68. 
82. Domingo Faustino Sarmiento, Facundo: Civilization and Barbarism, trans. Kathleen Ross (Berkeley, CA: University of California Press, 2003), 124.

83. Margrit Pernau, "Civility and Barbarism: Emotions as Criteria of Difference," in Emotional Lexicons: Continuity and Change in the Vocabulary of Feeling 1700-2000, ed. Ute Frevert et al. (Oxford: Oxford University Press, 2014), 256.

84. Para la historia. Efemérides sangrientas de la dictadura de Juan Manuel de Rosas. Con un apéndice de sus robos llamados confiscaciones (Montevideo: El Comercio del Plata, 1849), 71-72: “Aunque, como ya hemos dicho en nuestros artículos sobre los Robos de Rosas llamados Confiscaciones, lo entrado en dinero en la caja de este, como producto de ellas, solo representa una parte mínima de los valores confiscados, con todo, en sus Estados de esas entradas, que allí publicamos, pueden verse las injentes sumas que ingresaron pertenecientes á [Lucas] Gonzalez, y calcúlarse el inmenso capital que Rosas robó á su familia: como ingresaron otras muy cuantiosas, pertenecientes al sobrino de aquel, el Sr. Borbon, porteño, cuyos bienes fueron igualmente confiscados, y que tambien salvó su vida, ocultándose y asilándose en Montevideo".

85. I am referring here to Hayden White's notion of "narrative emplotment". Hayden White, Metahistory. The Historical Imagination in NineteenthCentury Europe (Baltimore, MD: Johns Hopkins University Press, 1979), 7-11.

86. Christoph Rosenmüller, "De lo innato a lo performativo: dos conceptos rivales de la corrupción, siglos XVII y XVIII," in "Dádivas, dones y dineros». Aportes a una nueva historia de la corrupción en América Latina desde el imperio español a la modernidad, ed. Christoph Rosenmüller and Stephan Ruderer (Frankfurt/Madrid: Iberoamericana Vervuert, 2016).

87. Engels, Die Geschichte der Korruption, 325-29. On the nexus between corruption and dictatorship in eighteenth and nineteenth century France and Italy, see Cesare Vetter, "Dictature: les vicissitudes d'un mot. France et Italie (XVIII et XIX siècles)." Révolution Française.net. Accessed May 22, 2020, https://revolution-francaise.net/2008/03/01/212-dictaturevicissitudes-mot-france-italie-xviii-xix-siecles.

88. David P. Jordan, "The Robespierre problem," in Robespierre, ed. William Doyle and Colin Haydon (Cambridge: Cambridge University Press, 1999) 18 and 21-22; Peter McPhee, Robespierre. A Revolutionary Life (New Haven, CT: Yale University Press, 2012), 233. For a juxtaposition of Dr. Francia and Robespierre, see Georges Fournial, "Rodriguez de Francia dictateur «robespierriste» du Paraguay (1814-1840)," Annales historiques de la Révolution française 242 (1980), https://doi.org/10.3406/ahrf. 1980.4230 .

89. Engels, Die Geschichte der Korruption, 166. 
90. Fureix, "Les émotions protestataires," 302.

91. Helmut Schoeck, Envy: A Theory of Social Behaviour, trans. Michael Glenny and Betty Ross (New York: Harcourt Brace and World, 1970), 198-99 and 350-51.

\section{REFERENCES}

Adelman, Jeremy. Sovereignty and Revolution in the Iberian Atlantic. Princeton, NJ: Princeton University Press, 2006.

Beaurepaire, Pierre-Yves. "The View from Below: The 1789 cahiers de doléances." In The Oxford Handbook of the French Revolution, edited by David Andress, 149-63. Oxford: Oxford University Press, 2015.

Bolufer Peruga, Mónica. "En torno a la sensibilidad dieciochesca: discursos, prácticas, paradojas." In Las mujeres y las emociones en Europa y América. Siglos XVII-XIX, edited by María Luisa Candau Chacón, 29-56. Santander: Editorial Universidad de Cantabria, 2016.

Botting, Douglas. Alexander von Humboldt. Translated by Annelie Hohenemser. München: Prestel, 2012.

Bouvet, Nora Esperanza. Poder y escritura. El doctor Francia y la construcción del Estado paraguayo. Buenos Aires: Editorial Universidad de Buenos Aires, 2009.

Bravo-Olmedo, Valentina. "«Le ofreció dinero para que no lo demandase». Justicia negociada y género en prácticas de resolución de conflictos por pensión de alimentos. Chile Central, 1788-1840." Trashumante. Revista Americana de Historia Social 11 (January-June 2018): 144-63. https://doi. org/10.17533/udea.trahs.nlla07.

Büschges, Christian. "«Las leyes del honor». Honor y estratificación social en el distrito de la audiencia de Quito (siglo XVIII)." Revista de Indias LVII, no. 209 (1997): 55-84. https://doi.org/10.3989/revindias.1997.i209.795.

Bustamante, Carlos María de (ed.). México por dentro y fuera, bajo el gobierno de los Vireyes. México: En la imprenta del ciudadano A. Valdez, 1831.

Caldcleugh, Alexander. Travels in South America, During the Years 1819-20-21. 2 vols. London: John Murray, 1825.

Cañeque, Alejandro. "The Emotions of Power: Love, Anger, and Fear, or How to Rule the Spanish Empire." In Emotions and Daily Life in Colonial Mexico, edited by Javier Villa-Flores and Sonya Lipsett-Rivera, 89-121. Albuquerque, NM: University of New Mexico Press, 2014.

Carlyle, Thomas. "Dr Francia." In Critical and Miscellaneous Essays: Collected and Republished by Thomas Carlyle, 253-312. 4 vols. $3^{\text {rd }}$ ed. London: Chapman and Hall, 1847. 
Catalano, Pierangelo. “Consolato e dittatura: L'“esperimento' romano della Repubblica del Paraguay (1813-1844).” In Dittatura degli antichi e dittatura dei moderni, edited by Giovanni Meloni, 151-72. Roma: Editori riuniti, 1983.

Chaves, Julio César. El Supremo Dictador. Biografía de José Gaspar de Francia. Madrid: Ediciones Atlas, 1964.

Chiaramonte, José Carlos. La Ilustración en el Rio de la Plata: Cultura eclesiástica y cultura laica durante el Virreinato. Buenos Aires: Puntosur, 1989.

Davis, Natalie Zemon. The Gift in Sixteenth-century France. Madison, WI: University of Wisconsin Press, 2000.

Delon, Michel. "L'éveil de l'âme sensible." In Histoire des émotions, edited by Alain Corbin, Jean-Jacques Courtine and Georges Vigarello, 11-42. 3 vols. Paris: Seuil, 2016-2017.

Di Meglio, Gabriel. ;Mueran los salvajes unitarios! La Mazorca y la politica en tiempos de Rosas. Buenos Aires: Editorial Sudamericana, 2007.

Echenberg, Myron. Humboldt's Mexico: In the Footsteps of the Illustrious German Scientific Traveller. Montreal: McGill-Queen's University Press, 2017.

Eckart, Wolfgang U. Geschichte, Theorie und Ethik der Medizin. Berlin, Heidelberg: Springer, 2013.

Elliott, John H. Imperial Spain 1469-1716. London: Penguin Books, 1963.

Engels, Jens Ivo. "Revolution und Panama. Korruptionsdebatten als Systemkritik in Frankreich vom 18. Jahrhundert bis zur Dritten Republik." In Geld Geschenke - Politik. Korruption im neuzeitlichen Europa, edited by Jens Ivo Engels, Andreas Fahrmeir and Alexander Nützenadel, 143-75. München: Oldenbourg, 2009.

Engels, Jens Ivo. Die Geschichte der Korruption. Von der Frühen Neuzeit bis ins 20. Jahrhundert. München: S. Fischer, 2014.

Entin, Gabriel. "Les formes de la république: monarchie, crise et révolution au Rio de la Plata." In Les Empires atlantiques des Lumières au libéralisme (17631865), edited by Federica Morelli, Clément Thibaud and Geneviève Verdo, 203-33. Rennes: Presses Universitaires de Rennes, 2009.

Ette, Ottmar. "Transatlantic Perceptions: A Contrastive Reading of the Travels of Alexander von Humboldt and Fray Servando Teresa de Mier." Dispositio 17, no. 42/43 (1992): 165-97.

Fournial, Georges. "Rodriguez de Francia dictateur «robespierriste» du Paraguay (1814-1840)." Annales historiques de la Révolution française 242 (1980): 608-14. https://doi.org/10.3406/ahrf.1980.4230.

Fradkin, Raúl O., and Jorge Gelman. Juan Manuel de Rosas. La construcción de un liderazgo político. Buenos Aires: Edhasa, 2015.

Frevert, Ute. Emotions in History - Lost and Found. Budapest, New York: Central European University Press, 2011.

Frevert, Ute. Vergängliche Gefüble. Göttingen: Wallstein Verlag, 2013. 
Fureix, Emmanuel. "Les émotions protestataires.” In Histoire des émotions, edited by Alain Corbin, Jean-Jacques Courtine and Georges Vigarello, 299-321. 3 vols. Paris: Seuil, 2016-2017.

Gil Amate, Virgina. "Hipólito Villarroel: una mirada ilustrada sobre la Ciudad de México." Tema y variaciones de literatura: México prehispánico y colonial: miradas contemporáneas 32 (2009): 255-87.

Goetzl, Ursula. "Alexander von Humboldt als Geschichtsschreiber Amerikas.” PhD diss., Ludwig-Maximilians-Universität München, 1966.

Goldman, Noemí. Historia y lenguaje: los discursos de la Revolución de Mayo. Buenos Aires: Centro Editor de América Latina, 1992.

Gómez, Leila. Iluminados y tránsfugas. Relatos de viajeros y ficciones nacionales en Argentina, Paraguay y Perú. Frankfurt/Madrid: Iberoamericana Vervuert, 2009.

Grafe, Regina, and Alejandra Irigoin. "A stakeholder empire: the political economy of Spanish imperial rule in America." The Economic History Review 65, no. 2 (April 2012): 609-51. https://doi.org/10.1111/j.1468-0289. 2010.00581.x.

Hernández Sotelo, Anel. "Hipólito Villarroel y las enfermedades políticas de la Nueva España." Boletín Cultural. Órgano Informativo y Cultural de la Escuela Nacional de Antropología e Historia 18 (2003): 13-24.

Humboldt, Alexander von. Essai politique sur le Royaume de la Nouvelle-Espagne. 5 vols. Paris: F. Schoell, 1811.

Humboldt, Alexander von. Political Essay on the Kingdom of New Spain. 2 vols. Translated by John Black. Cambridge: Cambridge University Press, 2014. https://doi.org/10.1017/CBO9781139923897.

Jones, Charles. "Robertson, John Parish.” Oxford Dictionary of National Biography. Accessed May 22, 2020. https://doi.org/10.1093/ref:odnb/23805.

Jordan, David P. “The Robespierre problem.” In Robespierre, edited by William Doyle and Colin Haydon, 17-34. Cambridge: Cambridge University Press, 1999.

Kahle, Günter. “ Ein südamerikanischer Diktator, Dr. Francia von Paraguay, im Spiegel der europäischen Geschichtsschreibung." Saeculum 15 (1964): 24959. https://doi.org/10.7788/saeculum.1964.15.jg.249.

Kottenkamp, Franz. Der Unabhängigkeitskampf der spanisch-amerikanischen Colonien. Stuttgart: Literatur-Comptoir, 1838.

López Bejarano, Pilar. “"Empapelar» al enemigo. El recurso a los procesos judiciales como estrategia de la acción política (Nueva Granada entre colonia y república)." In Justicias, agentes y jurisdicciones. De la Monarquía Hispánica a los Estados Nacionales (España y América, siglos XVI-XIX), edited by Elisa Caselli, 79-102. Madrid, México: Fondo de Cultura Económica de España/Fondo de Cultura Económica, 2016. 
Lynch, John. Argentine Dictator: Juan Manuel de Rosas 1829-1852. Oxford: Clarendon Press, 1981.

Lynch, John. "Spanish American Independence in Recent Historiography." In Independence and Revolution in Spanish America: Perspectives and Problems, edited by Anthony McFarlane and Eduardo Posada-Carbó, 13-42. London: Institute of Latin American Studies, 1999.

Lynch, John. Argentine Caudillo. Juan Manuel de Rosas. Oxford: SR Books, 2001.

Mazeau, Guillaume. "Émotions politiques: la Révolution française." In Histoire des émotions, edited by Alain Corbin, Jean-Jacques Courtine and Georges Vigarello, 98-142. 3 vols. Paris: Seuil, 2016-2017.

McFarlane, Anthony. "Political Corruption and Reform in Bourbon Spanish America." In Political Corruption in Europe and Latin America, edited by Walter Little and Eduardo Posada-Carbó, 41-63. Basingstoke, London: Macmillan / St. Martin's Press, 1996.

McPhee, Peter. Robespierre. A Revolutionary Life. New Haven, CT: Yale University Press, 2012.

Niles, John M. History of South America and Mexico. 2 vols. Hartford: H. Huntington, 1838.

O'Hara, Matthew D. "Anxiety, the Future, and Mexican Independence." In Emotions and Daily Life in Colonial Mexico, edited by Javier Villa-Flores and Sonya Lipsett-Rivera, 198-220. Albuquerque, NM: University of New Mexico Press, 2014.

Osterhammel, Jürgen. The Transformation of the World: a global history of the nineteenth century. Translated by Patrick Camiller. Princeton, NJ: Princeton University Press, 2014.

Para la historia. Efemérides sangrientas de la dictadura de Juan Manuel de Rosas. Con un apéndice de sus robos llamados confiscaciones. Montevideo: El Comercio del Plata, 1849.

Pernau, Margrit. "Civility and Barbarism: Emotions as Criteria of Difference." In Emotional Lexicons: Continuity and Change in the Vocabulary of Feeling 1700-2000, edited by Ute Frevert et al., 230-59. Oxford: Oxford University Press, 2014.

Plamper, Jan. The History of Emotions. An Introduction. Oxford: Oxford University Press, 2015.

Potthast, Barbara, and Ignacio Telesca. “¿Nueva jurisprudencia o pragmatismo político? Paraguay y su lucha por mantener la independencia." In Juristas de la independencia, edited by José María Pérez Collados and Samuel Barbosa Rodrigues, 521-82. Madrid: Marcial Pons, 2012.

Premo, Bianca. The Enlightenment on Trial. Ordinary Litigants and Colonialism in the Spanish Empire. Oxford: Oxford University Press, 2017. 
Premo, Bianca. "Lo extrajudicial. Between court and community in the Spanish empire." In The Uses of Justice in Global Perspective, 1600-1900, edited by Griet Vermeesch, Manon van der Heijden, and Jaco Zuijderduijn, 183-97. London: Routledge, 2019.

Prieto, Moisés. “«History's So Strong». The Topos of Historia Magistra Vitae and the Re-Discovery of Dictatorship in Latin America." History of Humanities 5, no. 1 (2020): 225-49. https://doi.org/10.1086/707700.

Prieto, Moisés. "Dictadura y sentimiento: las emociones en un relato europeo sobre el Doctor Francia, Supremo Dictador del Paraguay." Iberoamericana 18, no. 69 (September-December 2018): 127-50. https://doi.org/10.18441/ ibam.18.2018.69.

Raphael, Lutz. "Freiheit und Wohlstand der Nationen. Alexander von Humboldts Analysen der politischen Zustände Amerikas und das politische Denken seiner Zeit." Historische Zeitschrift 260, no. 3 (1995): 749-76. https://doi.org/10.1524/hzhz.1995.260.jg.749.

Ratto, Silvia. "¿Finanzas públicas o negocios privados? El sistema de racionamiento del negocio pacífico de indios en la época de Rosas." In Caudillismos rioplatenses. Nuevas miradas a un viejo problema, edited by Noemí Goldman and Ricardo Salvatore, 241-65. Buenos Aires: Eudeba, 1998.

Reddy, William M. "Sentimentalism and Its Erasure: The Role of Emotions in the Era of the French Revolution." The Journal of Modern History 72, no. 1 (2000): 109-52. https://doi.org/10.1086/315931.

Reddy, William M. The Navigation of Feeling: A Framework for the History of Emotions. Cambridge: Cambridge University Press, 2001.

Rengger, Johann Rudolph and Marcelin Longchamp, The Reign of Doctor Joseph Gaspard Roderick de Francia in Paraguay Being an Account of a Six Years' Residence in That Republic. London: Thomas Hurst, Edward Chance \& Co., 1827.

Rivera Indarte, José. Rosas y sus opositores. Montevideo: Imprenta del Nacional, 1843.

Robertson, John P., and William P. Robertson. Letters on Paraguay. 2 vols. London: John Murray, 1838.

Robertson, John P., and William P. Robertson. Four Years in Paraguay. 2 vols. Philadelphia: Carey \& Hart, 1838.

Robertson, William. "The History of America." In The Works of William Robertson. 12 vols. London, 1817.

Rosas and some of the Atrocities of his Dictatorship in the River Plate. London: Simmons and Clowes, 1844.

Rosenmüller, Christoph. Patrons, Partisans, and Palace Intrigues. The Court of Colonial Mexico, 1702-1710. Calgary: University of Calgary Press, 2008. 
Rosenmüller, Christoph. "De lo innato a lo performativo: dos conceptos rivales de la corrupción, siglos XVII y XVIII." In "Dádivas, dones y dineros». Aportes a una nueva historia de la corrupción en América Latina desde el imperio español a la modernidad, edited by Christoph Rosenmüller and Stephan Ruderer, 87-112. Frankfurt/Madrid: Iberoamericana Vervuert, 2016.

Rosenmüller, Christoph. "Corruption, Abuse, and Justice in the Iberian Empires." In Corruption in the Iberian Empires. Greed, Custom, and Colonial Networks, edited by Christoph Rosenmüller, 1-12. Albuquerque, NM: University of New Mexico Press, 2017.

Sarmiento, Domingo Faustino. Facundo: Civilization and Barbarism. Translated by Kathleen Ross. Berkeley, CA: University of California Press, 2003.

Schoeck, Helmut. Envy: A Theory of Social Behaviour. Translated by Michael Glenny and Betty Ross. New York: Harcourt Brace and World, 1970.

Shawcross, Edward. France, Mexico and Informal Empire in Latin America, 1820-1867. Equilibrium in the New World. Cham: Palgrave Macmillan, 2018.

Sparling, Robert. "Montesquieu on Corruption: Civic Purity in a PostRepublican World." In On Civic Republicanism. Ancient Lessons for Global Politics, edited by Geoffrey C. Kellow and Neven Leddy, 157-84. Toronto: University of Toronto Press, 2016.

Stoetzer, O. Carlos. El pensamiento politico en la América española durante el periodo de la emancipación (1789-1825). 2 vols. Madrid: Instituto de Estudios Políticos, 1966.

Stoetzer, O. Carlos. "The Importance of Classical Influences during the SpanishAmerican Revolutions." Jahrbuch für Geschichte von Staat, Wirtschaft und Gesellschaft Lateinamerikas 30, no. 1 (1993): 183-226.

Taithe, Bertrand. "Empathies, soins et compassions: les émotions humanitaires." In Histoire des émotions, edited by Alain Corbin, Jean-Jacques Courtine and Georges Vigarello, 364-81. 3 vols. Paris: Seuil, 2016-2017.

Thibaud, Clément. Libérer le Nouveau Monde. La fondation des premières républiques hispaniques (Colombie et Venezuela, 1780-1820). Bécherel: Les Perséides, 2017.

Torres Puga, Gabriel. "Rousseau en Nueva España: presencia y recepción antes de 1808." In Rousseau en Iberoamérica: Lecturas e interpretaciones entre Monarquía y Revolución, edited by Gabriel Entin, 67-85. Buenos Aires: Sb editorial, 2018 .

Trachsler, Heinrich. Reisen, Schicksale und tragikomische Abenteuer eines Schweizers. Zürich: Verlag von Heinrich Trachsler, 1839.

Vásquez Meléndez, Miguel Ángel. "Los ceremoniales en la construcción de la imagen del rey amable (Nueva España, 1789-1791).” In Amor e historia. La expresión de los afectos en el mundo de ayer, edited by Pilar Gonzalbo Aizpuru, 363-80. México D.F.: El Colegio de México, 2013. 
Vetter, Cesare. "Dictature: les vicissitudes d'un mot. France et Italie (XVIII et XIX siècles)." Révolution Française.net. Accessed May 22, 2020. https://revolution-francaise.net/2008/03/01/212-dictature-vicissitu des-mot-france-italie-xviii-xix-siecles.

Villoro, Luis. "Rousseau en la Independencia mexicana." Casa del Tiempo 7 (2005): 55-61.

Volosin, Natalia A. Corruption in Argentina. Towards an Institutional Approach. London: Routledge, 2019.

White, Hayden. Metahistory. The Historical Imagination in Nineteenth-Century Europe. Baltimore, MD: Johns Hopkins University Press, 1979.

Zeuske, Michael. "The French Revolution in Spanish America: With Some Reflections on Manfred Kossok as Marxist Historian of 'Bourgeois Revolutions'." Review 38, no. 1/2 (2015): 99-145.

Open Access This chapter is licensed under the terms of the Creative Commons Attribution 4.0 International License (http://creativecommons.org/licenses/ by $/ 4.0 /)$, which permits use, sharing, adaptation, distribution and reproduction in any medium or format, as long as you give appropriate credit to the original author(s) and the source, provide a link to the Creative Commons licence and indicate if changes were made.

The images or other third party material in this chapter are included in the chapter's Creative Commons licence, unless indicated otherwise in a credit line to the material. If material is not included in the chapter's Creative Commons licence and your intended use is not permitted by statutory regulation or exceeds the permitted use, you will need to obtain permission directly from the copyright holder.

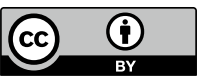

